\title{
HMONG. THE SECRET ARMY
}

\author{
George BIZADEA ${ }^{574}$
}

\begin{abstract}
This article aims to analyze the role of the Hmong population in the Indochina conflict. US President Dwight D. Eisenhower considered Laos a buffer state according to the Dominion Theory and as such much more strategically important than Vietnam. To avoid the fall of Laos under communism and thus the spread of communism in the region, Eisenhower turned to the services of the C.I.A., because he could not intervene officially in Laos without violating the Geneva Convention.
\end{abstract}

Keywords: Indochina; Laos; Vietnam; war; United States of America; Hmong, Central Intelligence Agency.

The first bomb was dropped from a flying machine in 1911. More precisely, in the Libyan desert area, a hand grenade was thrown from a biplane on an oasis without causing any damage or material damage. Just 34 years later, the United States dropped the Hiroshima bomb, which leveled an entire city, killing more than 100,000 people. Just 19 years after the Hiroshima disaster, the United States was launching a bombing campaign on Laos, which would prove to be the most violent in history. From 1964 to 1973, the United States dropped more than 2,000,000 tons of bombs on Laos (more than on Nazi Germany and Japan in World War II). According to military analysts, a bomb was dropped on Laos every 8 minutes for 9 years, making it the most bombed nation in history. ${ }^{575}$

After the end of the Second World War, global geopolitics took on a completely different dimension. We could observe in that period the radical transformation of the world chessboard and its evolution towards a world characterized by an ideological bipolarity. Thus, we could observe a current oriented towards independence, a current that spread rapidly in the colonial territories of Great Britain and France. The Southeast Asia area was no exception to this paradigm. ${ }^{576}$

After 1945 Ho Chi Minh along with three Laotian princes (Hoang Than Phetsarath, HT Souvanna Phouma, HT Souphanouvong) laid the foundations of a current national liberation, which was expected to include all Southeast Asian states. In their efforts to ensure the independence of Laos, a situation complicated

\footnotetext{
${ }^{574} \mathrm{Mr}$. George Bizadea is manager and representative of the civil society.

${ }^{575}$ Martin Stuart, Fox, History of Laos, Cambridge University Press, 1997, p.132.

${ }^{576}$ Robert Kaplan, Asia's Cauldron:The South China Sea and the End of a Stable Pacific, Random House Trade, 2015.
} 
by the diversity of existing ethnic groups in the country (over 50 ethnic groups), these three princes have created three political factions as follows;

- communist faction (pro-Vietnam and supported by the Soviet Union);

- neutralist faction (supported by the USA);

- conservative royalist faction (supported by the USA). ${ }^{577}$

To create a strong communist faction in Laos, Prince Souphanouvong joined the Indochinese Communist Movement. In 1950, Prince Souphanouvong organized the first congress of the Laotian Liberation Front (better known as Pathet Lao).

All of these power games inside Indochina have caused concern in Washington, fueling fears of North Americans as North Vietnamese troops enter Laos.

The country of the 1000 elephants, also called Laos, was declared a neutral state in 1954. On March 23, 1961, American President J.F. Kennedy said the security of Southeast Asia would be in jeopardy if Laos lost its neutrality. Officially, both Kennedy and Nikita Khrushchev stated that Laos should not become a theater of war.

In 1954 the ICC (International Control Commission) was established. This commission was tasked with monitoring compliance with Laos' neutrality under the Geneva Convention. The Laos commission delegation consisted of diplomats and military personnel from Poland, Canada, and India. In the beginning, the commission played an active role, until the moment when they found out about the massive movements of the troops belonging to North Vietnam on the territory of Laos. Trying to document this violation of the Geneva Convention, they traveled by air (helicopter) to the area and were attacked by Vietnamese troops, managing to escape at the last minute. Since then, the commission has not operated inside Laos, limiting itself to a sterile presence in the capital Vientiane. ${ }^{578}$

Moreover, the work of the commission was hampered by bureaucracy within it and later boycotted by the Polish delegation (they were playing the games of the Soviet Union and North Vietnam). NBC News journalist Ted Yates, who was in Vientiane at the time, described in a video report the situation in the capital, where he observed the presence of all three armies involved in the conflict (the communist army Pathet Lao, the neutralist army, and the royalist army), a bizarre mutual acceptance. Paraphrasing it, he said, "Alice in Wonderland fast feeling."

At the Geneva Convention of 23 July 1962, Laos's neutrality was reconfirmed. Among other things, the agreement stipulated that no foreign power was allowed to use the territory of Laos to attack any of the neighboring countries and forced the withdrawal of all foreign troops from its territory. Thus, in 1963, a

\footnotetext{
${ }^{577}$ Lee Vang, Jaime Meyer, Hmong! The CIA ’s Secret Army, Great American History Theatre, 1999, p.45.

${ }^{578}$ Michael H. Hunt, A Vietnam War Reader, University of North Carolina Press, p.134.
} 
government of national unity was formed and the United States officially withdrew its military advisers from Laos.

US President Dwight D. Eisenhower considered Laos a buffer state according to the Dominion Theory and as such much more strategically important than Vietnam. To avoid the fall of Laos under communism and thus the spread of communism in the region, Eisenhower turned to the services of the C.I.A., because he could not intervene officially in Laos without violating the Geneva Convention. ${ }^{579}$

The Agency tasked Bill Lair (James William Lair) with assessing the situation and creating a battle plan. Bill Lair, a CIA officer with extensive experience in the Indochina area who had successfully operated for more than ten years in Thailand, was given the mission to stop the Vietnamese and those in Pathet Lao in their attempt to turn Laos into a communist state. He came up with the idea of using the Hmong tribes (Hmong in translation = free people). The Hmong people seemed the right choice because it was a population oppressed by the Vietnamese and Pathet Lao. Originally from Mongolia, the Hmong (mountain people) tribes were ideal for guerrilla warfare. The military advisers of the C.I.A. were reintroduced to Laos under diplomatic immunity, under the disguise, as military attachés at the US embassy in Vientiane.

The leader of the Hmong people, General Vang Pao, a ruthless commander, saw an opportunity in the alliance with Bill Lair in his attempt to save the Hmong people from annihilation. General Vang Pao was a commander more than prepared for guerrilla warfare, with extensive military experience in theaters of operations, and a veteran of the French Army, with whom he had fought together against the Japanese invasion of World War II.

Thus, the most appropriate scenario to follow, under the name of "Operation Momentum", took shape. In the first phase of the operation, 1,000 Hmong fighters were armed with weapons from the World War II surplus. Knowing that from the moment of parachuting the weapons to the Vietnamese counterattack, attracted by them, Vang Pao has a respite of about four days, he set up with Bill Lair a lightning training program for the 1000 soldiers for only three days. Using Lair's tactics, the Hmong army was immediately successful against the North Vietnamese army. Fueled by these successes, US partners sent more and more weapons and advisers to the area, making it possible to arm more than 15,000 Hmong fighters in six months. In time, General Vang Pao's army numbered grew to 40,000 soldiers. Later Hmong fighters were equipped with artillery batteries, mortars, anti-tank weapons, and modern infantry weapons (M16, M60 etc). C.I.A. in addition to equipping the fighters with all the logistics needed to wage a war (weapons, ammunition, military equipment, medicine, food), also offered them a salary of $\$$ 3 a month, even if they had not demanded payment. ${ }^{580}$ Vang Pao being aware of

\footnotetext{
${ }^{579}$ Tim Weiner, O istorie a C.I.A., Editura Litera, București, 2019, p.252.

${ }^{580} \mathrm{https} / / / \mathrm{www} . c i a . g o v /$ readingroom/collection/vietnam-collection, accessed on June 1, 2020.
} 
corruption in the Laotian army, insisted that the sums of money from the C.I.A. reach him directly; to make sure the money gets to his troops. The aggressiveness of the Hmong fighters was so great that the North Vietnamese army was forced to wage a counterinsurgency war. ${ }^{581}$

In addition to the Hmong fighters, C.I.A. also hired volunteer fighters (mercenaries) from Thailand (about 8000 people) to help the war effort.

The importance of creating a strong Hmong army in Laos had two main objectives: Pathet Lao)

1. Attempt to prevent Laos from falling under communism (countering

2. Disruption and destruction of the North Vietnam supply network to South Vietnam via Laos (an integral and indispensable part of the Ho Chi Minh Trail). ${ }^{582}$

James R. Lilley (US Ambassador to China in 1989), when he was CIA's deputy in Laos, said the political climate in Laos was deeply corrupt. Mr. Lilley said the massive US infusion of capital into Laos (\$ 550 million), the influence of the political climate towards a democratic path, the attempt to create local elections, the creation of a constitution only increased the level of corruption, because, the country was not prepared for such radical changes, as there was no real political will and an adequate degree of popular understanding. ${ }^{583}$

In addition to supporting ground troops, Langley advisers quickly understood the need to create a Hmong air force to be able to provide CAS (close air support) to field fighters. As a result, they trained a group of Hmong aviators in Thailand, which they equipped with T-28 aircraft, giving rise to the Royal Lao Air Force (RLAF). Initially equipped with only 8 T28 aircraft, their number soon reaches 40 T28 aircraft. Hmong aviators were so dedicated to their cause those American instructors were impressed by their devotion and skills. In a short time, Hmong aviators reached the amazing performance of being able to perform an average of 8-11 missions a day. For their courage, Hmong pilots were rewarded with the US $\$ 1,500$ a month, and in addition, they received $\$ 1.5$ for each mission. ${ }^{584}$ In 1964, CIA advisers along with USAF Brigadier General Harry C, Aderholt (Heinie Aderholt), commander of Special Air Operations in Southeast Asia, understood the strategic importance of flight controllers marking targets for Hmong aviation and soon after the FAC - Raven (Raven Forward Air Controller) body was created. These controllers were secretly recruited from the US Air Force where they resigned and were employed as civilian personnel, under false identities, to carry out FAC missions (locating and marking enemy targets). Of the 200 controllers, 23 died in Laos. Because they operated as civilian personnel, Raven's controllers in the case of capture were not under the protection of the

\footnotetext{
${ }^{581}$ Lee Vang, Jaime Meyer, op.cit, pp.65-68.

${ }^{582}$ Davies Peter E, Ho Chi Min Trail 1964-1973, Steel Tiger, Barrel Roll and the secret air wars in Vietnam and Laos, Osprey Publishing, 2020, p.35.

${ }^{583}$ John Lewis Gaddis, The Cold War- The Deals. The Spies. The Lies. The Truth, Penguin Books Ltd, 2007, p.254.

${ }^{584}$ Lee Vang, Jaime Meyer, op.cit. p.71.
} 
Geneva Convention on prisoners of war. In 1973, the FAC mission ended. According to Brigadier General Heinie Aderholt, the FAC mission and all the secret war in Laos blocked 10 Vietnamese divisions.

To keep the Laotian side of the Ho Chi Minh Trail functional, the North Vietnamese army increased its numbers to about 75,000 soldiers. Of these, 50,000 were used for the Ho Chi Minh Trail, and the remaining 25,000 were used alongside the Pathet Lao Army on offensive missions against the Hmong Army.

To support the Hmong Army's war effort, the C.I.A. was forced by circumstances to find viable solutions for its supply. Because this army operated in the mountainous areas of Laos, all the necessary equipment had to be brought by air. To maintain the strict secrecy of operations, the C.I.A. used 3 "private" airlines for 11 years, as a screen, as follows:

- $\quad$ Continental Air Service Inc (C.A.S.I.);

- $\quad$ BirdAir;

- $\quad$ Air America ${ }^{585}$.

\section{"THE WORST THING BESIDES FLYING TO LAOS IS LANDING IN LAOS"}

This popular saying among American pilots employed by the abovementioned companies best paraphrases the state of mind in that period. These pilots were constantly exposed to the firing of enemy anti-aircraft artillery, being forced to fly in extreme weather conditions, slaloming through mountain ridges, and trying to land on makeshift runways from the ground under the firing of enemy mortars and infantry weapons. In most cases, they did not stop the aircraft engines, unloaded the cargo at the highest speed, and took off immediately. Another risk to which they were exposed was that of "unfriendly runways", sometimes finding out only after landing that the runways were in the hands of the enemy. The pilots came from the ranks of retired military pilots, the vast majority of World War II veterans. The average age of the pilots was 43 years. Despite the experience, many of them did not return home, the mortality rate is about $20 \%$. Along with the risk came benefits, the salary of a pilot rising to a colossal value for that period (over 3000 USD / month).

Air America alone, as a case study, carries about 120,000 tons of cargo and more than 10,000 people a month. It performed about 900 flights a day and operated on about 400 runways. Air America uses large aircraft (C123, C130, DC3 Dakota, etc.), small aircraft (Pilatus PC6, U-10D, etc.), and helicopters (UH1, Bell 47, etc.). The official annual spending budget, for Air America alone, was \$ $11,000,000$.

All this monumental war effort had as its main base, the airbase at Long Tieng (also known as the base at Long Chen or Spook Haven = spy paradise). The

\footnotetext{
585 John Lewis Gaddis, op.cit., p.175.
} 
base code name was LS-20 (Lima Site 20). Large transport planes landed at this base. From here, war materials were loaded into smaller planes or helicopters and distributed to other bases. Excluding the other two airlines, the survival of more than 120,000 Hmong people depended on Air America alone. The Long Chen base was also used by T-28 aircraft belonging to the Laotian Air Force. Due to the special concentration of forces, Long Chen became the second urban agglomeration in Laos. Composed of Hmong fighters, their families, Thai mercenaries, American pilots, and spies. The Chen Chen base operated an average of 400 flights a day. ${ }^{586}$

Of similar importance to that of the LS-20 (Lima Site 20) for US military strategists was the LS-85 base (Lima Site 85), a vital base for the ROLLING THUNDER campaign (North Vietnam bombing campaign). Located on Phou Pha Thi Mountain, the secret base TACV (Tactical Air Navigation), codenamed LS85 took shape in 1965 when construction began on radar installations and the necessary infrastructure. The technicians of this top-secret base were USAF (United States Air Force) soldiers detached from the SAC (Strategic Air Command), with false identities, disguised as Lockheed civilian contractors. The security of the American personnel and implicitly of the installations was ensured by elements of the Hmong army (about 1300 soldiers). Since 1967, thanks to the secret TACV LS-85 base, American aviation has been able to engage targets in North Vietnam day and night, in any weather. $20 \%$ of all North Vietnam bombing missions were directed from this base. Pathet Lao troops along with their Vietnamese allies launched numerous ground offenses without success. ${ }^{587}$

On January 12, 1968, two AN-2 biplanes belonging to the North Vietnamese air force bombed the base but without causing material damage or human casualties. Pilot Ted Moore and his co-pilot Ted Woods were flying near the base, onboard their UH-1B Huey helicopter, spotted the two enemy biplanes, and attacked them with the only weapon on board (one AK-47). They engaged one of the two enemy targets and managed to shoot it down, recording the first air victory in the history of a helicopter against a plane.

Plain of Jars, a magnificent place of great importance for the history of mankind. About 3,000 years old, this archeological site is considered to be one of the most important in Southeast Asia. After US Secretary of State Henry Kissinger authorized the bombing campaign on Laos, the Plain of Jars and the Ho Chi Minh Trail (the part that passed through Laos) became the most bombed areas in Laos. Following the data provided by, U.S. Department of Defense, U.S. airplanes carried out 520,000 bombing missions in Laos (peaking at 1,300 missions/month), making it the most bombed country in history per capita. The situation was so complicated that American planes that had bombing missions in North Vietnam

\footnotetext{
${ }^{586}$ Lee Vang, Jaime Meyer, op.cit. p.74.

${ }^{587}$ Martin Stuart, op.cit, p. 158.
} 
and for various reasons could not drop bombs on the targets, were forced to drop the cargo on the Plain of Jars.

Until the retreat in 1975, the Hmong army, due to the losses suffered in so many years of war, had become composed mainly of children aged 11-12.

Two weeks after the fall of Saigon, in mid-May 1975, Pathet Lao took power in Laos. The CIA hastily evacuated the secret base of Long Chen (LS-20), taking with them 300 ethnic Hmong. The remaining few thousand were left behind and continued the fight with the communist regime Pathet Lao. In September 2008, 8,000 ethnics Hmongs were still in the armed struggle against the communist regime, the remnants of the CIA's secret army. ${ }^{588}$

After the war, Vang Pao left Laos and settled in the United States, where he became the leader of the Hmong community. Currently, 250,000 ethnic Hmong live in the United States.

The result of the CIA's secret war in Laos can be said to have been a negative one. Laos and Vietnam fell under the rule of communism. One-third of Laos's population perished in this terrible war. Even in 2021, its negative effects on Laos are obvious. Farmers cannot do mechanized farming because of unexploded bombs. Almost 50 years after the bombing stopped, about 150 people (especially children) are killed annually by unexploded ordnance. Experts estimate that $30 \%$ of aviation bombs dropped on Laos did not explode on impact (the most dangerous being cluster bombs). ${ }^{589}$

\section{BIBLIOGRAPHY}

- Davies Peter E., Ho Chi Min Trail 1964-1973, Steel Tiger, Barrel Roll and the secret air wars in Vietnam and Laos, Osprey Publishing, 2020.

- Emerson S., The Battle for Laos, Vietnam's Proxy War 1955-1975, Pend and Sword Books, 2019.

- Fontaine A., Istoria Războiului Rece, Editura Militară, București, 1994.

- Hunt M.H., A Vietnam War Reader, University of North Carolina Press, 2010.

- Kaplan R., Asia's Cauldron:The South China Sea and the End of a Stable Pacific, Random House Trade, 2015.

- Kaufmann W.F., The McNamara Strategy, Harper and Row Publisher, 1994.

- Stuart M., Fox, History of Laos, Cambridge University Press, 1997.

- Vang L., Meyer J., Hmong! The CIA's Secret Army, Great American History Theatre, 1999.

- Weiner T., O istorie a C.I.A., Editura Litera, București, 2019.

\footnotetext{
${ }^{588}$ André Fontaine, Istoria Războiului Rece, Editura Militară, București, 1994, p.258.

${ }^{589}$ Stephen Emerson, The Battle for Laos, Vietnam's Proxy War 1955-1975, Pend and Sword Books, 2019, p.128.
} 


\section{Online sources:}

- The CIA's secret war in Laos, https://www.youtube.com/watch? $\mathrm{v}=$ hdROxwo_2NM

- https://www.youtube.com/watch?v=I5OiM0TLh

- https://www.youtube.com/watch?v=HPLHjgaLPJ0

- https://www.youtube.com/watch? $\mathrm{v}=$ hoahIuqylgw

- https://www.youtube.com/watch?v=1_0WbPq2lhs

- https://www.cia.gov/readingroom/collection/vietnam-collection 